\title{
Primary Mucosal Malignant Melanoma: Two Case Reports
}

\author{
Primer Mukozal Malign Melanom; iki Olgu Sunumu
}

(D) Kevser Esmeray Çifci¹, (D) Yeşim Karagöz¹, (D) Çağrı Erdim¹, (D) Cem Leblebici², (D) Özgür Kılıçkesmez¹

1Sarıca Farabi Training and Research Hospital, Clinic of Radiology,Kocaeli, Turkey

2istanbul Training and Research Hospital, Clinic of Pathology, İstanbul, Turkey

\begin{abstract}
Primary mucosal malignant melanomas originate from melanocytes in mucosal membranes, which are located in the respiratory, gastrointestinal and urogenital tract. Mucosal melanomas are extremely rare and have a more aggressive and poor prognosis than skin melanoma. Local or distant metastasis, recurrence probability and mortality rates are higher. Although there are many epidemiological and etiological differences between mucosal melanomas and skin melanomas, there is no clear predisposing factor for mucosal melanomas. Mucosal melanomas constitute $1.3-1.4 \%$ of all melanomas, and $25-50 \%$ of these cases are head and neck tumors. The symptoms are non-specific and vary according to the location of the lesion. Knowing the typical radiological imaging characteristics of mucosal melanomas and its consideration in the differential diagnosis in clinical evaluation will increase the chance of early diagnosis and will positively affect the survival of patients.

We present the radiological imaging characteristics and clinical course of a 57-year-old male patient who presented with a complaint of parotid mass and who died in a short period of time with widespread metastases, and a 72-yearold male patient who presented with epistaxis and who had no metastasis in the postoperative follow-up, but had a local recurrence.
\end{abstract}

Keywords: Mucosal melanoma, extracutaneous, MRI öz

Primer mukozal malign melanomlar respiratuvar, gastrointestinal ve ürogenital traktta bulunan mukozal membranlardaki melanositlerden köken alır. Mukozal melanomlar oldukça nadirdir ve deri melanomuna göre daha agresif ve kötü prognozludur. Bölgesel veya uzak metastaz ve rekürrens olasılıkları ve mortaliteleri daha yüksektir. Mukozal melanomlar ile deri melanomları arasında epidemiyolojik ve etiyolojik pek çok fark bulunmakla birlikte mukozal melanomlar için net olarak tanımlanmış bir predispozan faktör bulunmamaktadır. Mukozal melanomlar tüm melanomların \%1,3-1,4'ünü oluşturur ve bu olguların \%25-50'si baş-boyun kaynaklı tümörlerdir. Semptomlar non-spesifik olup lezyonun yerleșim yerine göre değișmektedir. Mukozal melanomların tipik radyolojik görüntüleme özelliklerinin bilinmesi ve klinik değerlendirmede ayırıcı tanıda akla gelmesi, erken tanı şansını artıracak ve hasta sağ kalımını olumlu etkileyecektir.

Parotis lojunda kitle șikayetiyle bașvuran ve kısa zamanda yaygın metastazlar ile hayatını kaybeden 57 yașında erkek hasta ve epistaksis ile başvuran ve postoperatif takibinde metastazı bulunmayan, fakat lokal nüks saptanan 72 yaşında erkek hastanın radyolojik görüntüleme özelliklerini ve klinik gidişini sunmaktayız.

Anahtar Kelimeler: Mukozal melanom, ekstrakütanöz, MRG

\section{Introduction}

Primary mucosal malignant melanomas originate from melanocytes in mucosal membranes, which are located in the respiratory, gastrointestinal and urogenital tract. Mucosal melanomas are very rare and have a more aggressive and poor prognosis than skin melanoma (1). Although there are many epidemiological and etiological differences between mucosal melanomas and skin melanomas, there is no clear predisposing factor for mucosal melanomas (2).

Knowing the typical imaging characteristics of mucosal melanomas, which are very rare and have poor prognosis and its consideration in differential diagnosis, will contribute to early diagnosis.
Address for Correspondence/Yazıșma Adresi: Kevser Esmeray Çifci MD, Sarıca Farabi Training and Research Hospital Clinic of Radiology, Kocaeli, Turkey

Phone: +90 5053241139 E-mail: kevser.esmeray@yahoo.com ORCID ID: orcid.org/0000-0002-8518-7390

Cite this article as/Atıf: Çifci KE, Karagöz Y, Erdim Ç, Leblebici C, Kılıçkesmez Ö. Primary Mucosal Malignant Melanoma: Two Case Reports. İstanbul Med J2019; 20(3): 246-9.

(c) Copyright 2019 by the Istanbul Training and Research Hospital/Istanbul Medical Journal published by Galenos Publishing House.

(C) Telif Hakkı 2019 İstanbul Ĕgitim ve Araștırma Hastanesi/Istanbul Tıp Dergisi, Galenos Yayınevi tarafından basılmıștır.
Received/Geliș Tarihi: 08.05.2017 Accepted/Kabul Tarihi: 18.06.2018 
The aim of this study was to present two cases of primary mucosal malignant melanoma and to discuss its clinical and radiological features.

\section{Case Reports}

\section{Case 1}

A 52-year-old male patient presented with swelling in the parotid gland region. Ultrasonographic examination revealed hypoechoic solid nodular lesions in the parotid gland. After detecting malignant melanoma infiltration with fine needle aspiration biopsy, positron emission tomography-computed tomography (PET-CT) examination was performed, and intense fluorodeoxyglucose uptake was observed in the parotid gland in two foci and gallbladder. Abdominal magnetic

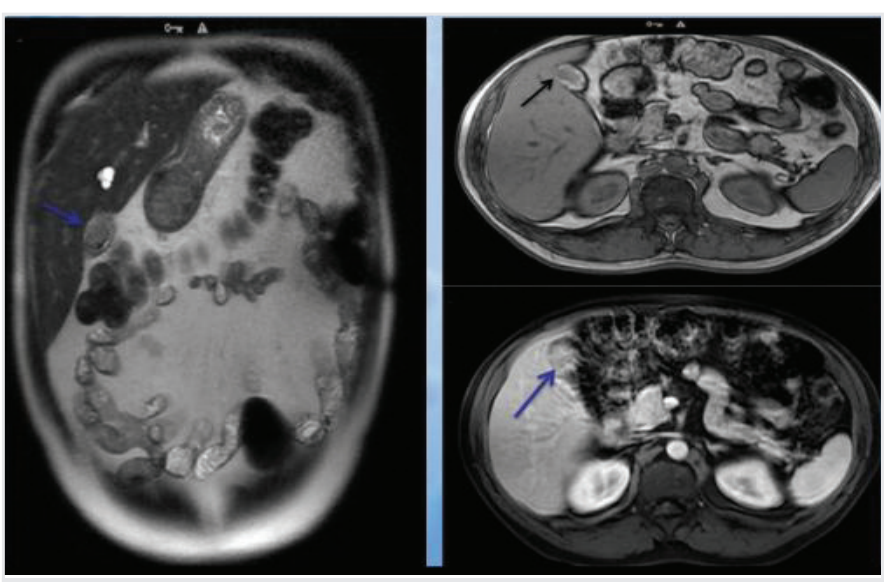

Figure 1. Primary malignant melanoma infiltration of the gallbladder with isointense appearance on coronal T2-weighted images, hyperintense appearance on axial T1-weighted images and prominent contrast enhancement on fat-suppressed T1-weighted images
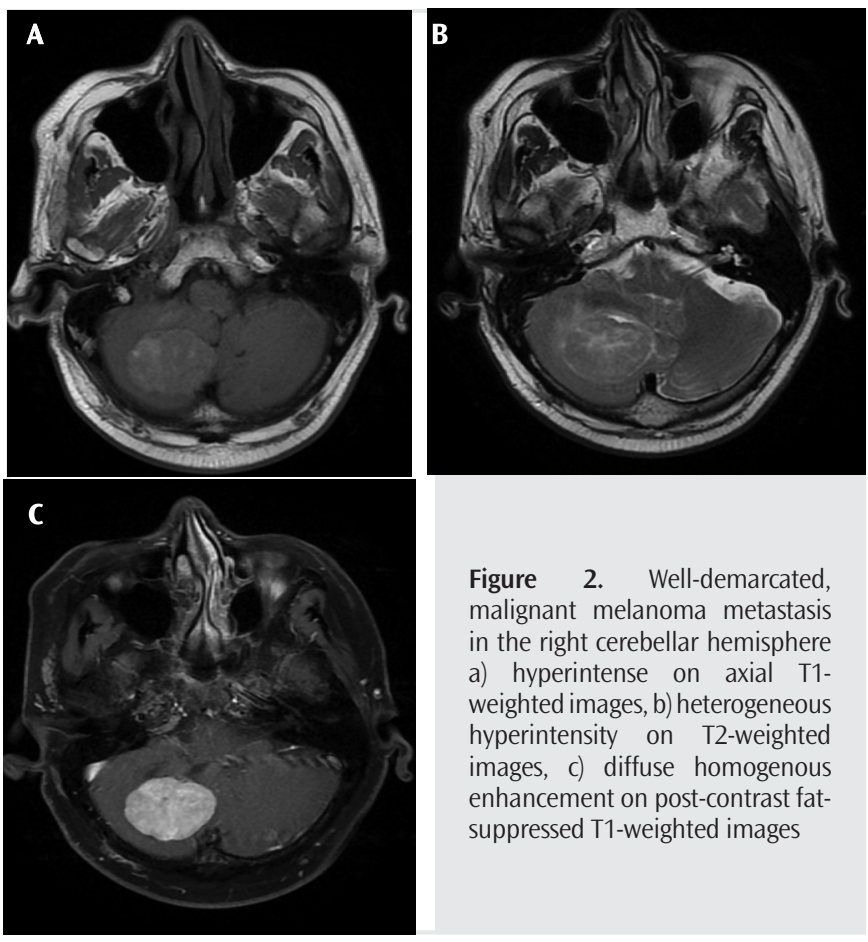

Figure 2. Well-demarcated, malignant melanoma metastasis in the right cerebellar hemisphere a) hyperintense on axial T1weighted images, b) heterogeneous hyperintensity on T2-weighted images, c) diffuse homogenous enhancement on post-contrast fatsuppressed T1-weighted images resonance imaging (MRI) showed a polypoid mass lesion with contrast enhancement in the gallbladder (Figure 1). Although primary malignant melanomas originating from parotid and gallbladder were very rare, the gallbladder was considered as the primary focus after histopathological examination. After the surgeries were performed, the patient was treated with radiotherapy and chemotherapy, and the patient was accepted in remission and early follow-up was performed with PET-CT at 3-month intervals. The PET-CT evaluation of the patient, who did not have recurrence for fourteen months, revealed metastases in the rectum and the small curvature of the stomach, and this diagnosis was confirmed by biopsy. Three months later, PET-CT revealed disseminated metastases in the soft tissue and cerebellum metastasis (Figures 2a,b,c), and the patient died in a short time. Figure 2a shows the typical hyperintensity of melanoma metastasis on T1-weighted imaging (WI). Figure $2 \mathrm{c}$ shows intense, diffuse and homogenous uptake and hypervascular nature of the melanoma metastasis. The survival of the patient from presentation was 22 months. Written informed consent was not obtained from the patients due to retrospective design of the study.

\section{Case 2}

A 70-year-old male patient was admitted to our otolaryngology clinic with complaint of epistaxis. Examination revealed polypoid mass in the right inferior concha. In the pre-operative imaging of the patient, CT scan revealed a mass lesion extending from the inferior right concha to the posterior of the nasopharynx. Contrast-enhanced facial MRI showed polypoid lesion with no extramucosal extension, which was isointense with mucosa on T1-W sequence and hypointense on T2weighted sequence, which had similar enhancement pattern with
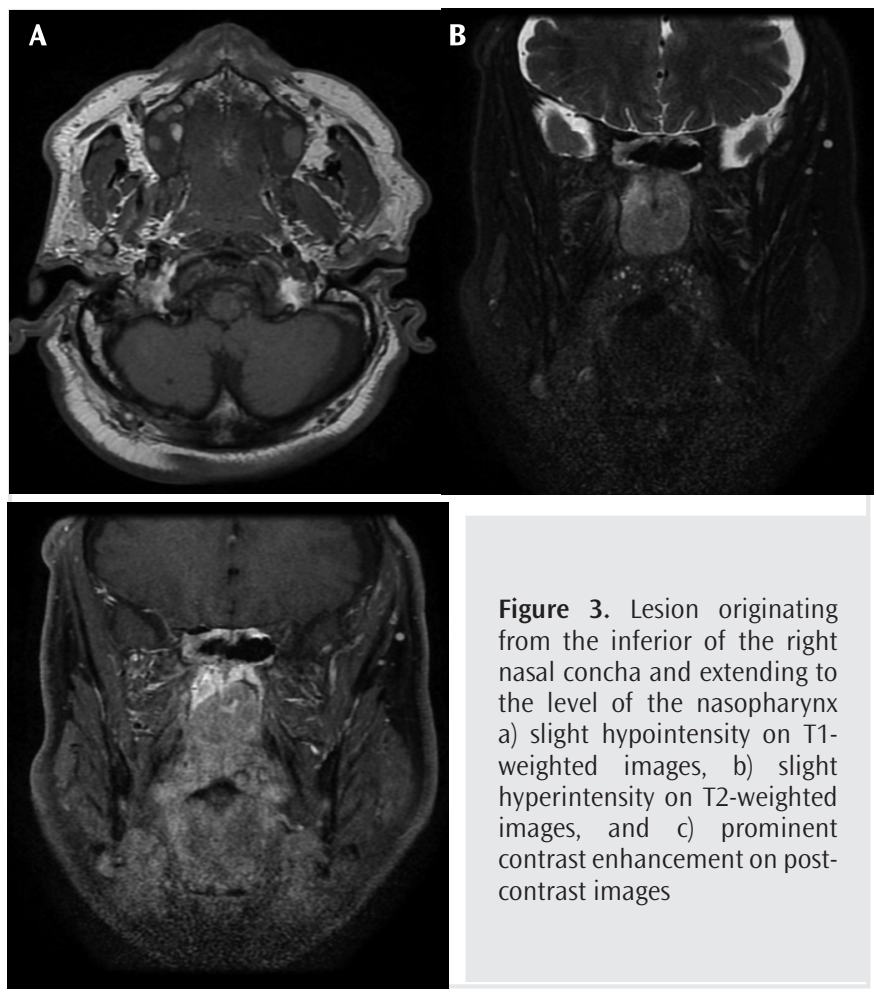

Figure 3. Lesion originating from the inferior of the right nasal concha and extending to the level of the nasopharynx a) slight hypointensity on T1weighted images, b) slight hyperintensity on T2-weighted images, and c) prominent contrast enhancement on postcontrast images 
mucosa on the post-contrast images and which could not be clearly differentiated from inflammatory polyp (Figures 3a,b,c). Frozen section consultation was reported as " $15 \mathrm{~mm}$ diameter tumor, $5 \mathrm{~mm}$ mucosal extension with negative margins and non-specific chronic inflammation at the posterior tumor margin and right maxillary sinus resection". In immunohistochemical studies, neoplastic cells were identified as \$100 $(+)$ and HMB45 (+) malignant melanoma. No distant metastasis was detected in PET-CT. Skin melanoma was not found in the dermatological examination of the patient. At the post-operative $2^{\text {nd }}$ month follow-up examination, recurrence was considered and biopsy was performed. The biopsy result was reported as recurrent malignant melanoma in the posterior half of the nasal cavity. Written informed consent was not obtained from the patients due to retrospective design of the study.

\section{Discussion}

Mucosal melanomas are more aggressive than skin melanomas. These are more likely to have local or distant metastasis and recurrence, and have a higher mortality. Mucosal melanomas account for $1.3-1.4 \%$ of all melanomas, and $25-50 \%$ of these cases originate from head and neck tumors. Nasal cavity, oral cavity and paranasal sinuses are the most common sites of the mucosal melanomas in the head and neck region (3). The second common site is the gastrointestinal tract, which accounts for $25 \%$ of all mucosal melanoma cases. The most common localizations in the gastrointestinal tract are the anorectal mucosa, the esophagus and the small intestine. Urogenital tract melanomas have the same incidence as the gastrointestinal tract by forming $20 \%$ of all mucosal melanomas, but due to the fact that vulvovaginal melanomas are in this group, the incidence of these melanomas is high in women (4). Primary extracutaneous melanomas in the parenchymatous organs have been reported in very few cases. Melanomas seen in the retroperitoneal region and parenchymatous organs, such as the lung and prostate, constitute only $5 \%$ of the extracellular malignant melanomas $(4,5)$.

The symptoms are non-specific and vary according to the location of the lesion. The most common symptom in the head and neck region is bleeding and unilateral nasal obstruction. In the anorectal area, it is commonly seen as a polypoid mass and may cause rectal bleeding, abdominal pain and difficulty in defecation.

Vulvar melanomas are the most common type of urogenital melanoma and share similar symptoms with other malignancies in this region. Symptoms include pruritus, irritation, and vaginal discharge. Vulvar melanomas are seen as an ulcerated, bleeding mass lesion in clinical examination and are often not pigmented (1-5,6). The metastasis pattern in mucosal melanomas varies according to the location of the primary site. In vaginal melanomas, early peritoneal invasion occurs due to the close anatomical relation and distant metastases may occur without regional lymph node involvement. Sinonasal melanomas often metastasize to the liver. Lymph node involvement is seen in $60 \%$ of anorectal melanomas and the first region of invasion of anal melanomas is inguinal lymph nodes (3-7).

Radiological evaluation is required for diagnosis, staging, preoperative planning and treatment follow-up in metastatic patients receiving systemic treatment. MRI is the primary imaging modality for the evaluation of local disease. CT and PET-CT have limited utility in the evaluation of local disease, and they play a primary role in the detection of metastatic disease (2). MRI appearance of the mucosal melanoma varies according to the histological features of the lesion and the presence of bleeding. Melanotic melanomas are hyperintense on T1WI and iso-hypointense on T2-WI due to the paramagnetic effect of melanin. Amelanotic melanomas are usually hypointense on T1-WI and hyperintense on T2-WI. In addition to conventional MRI sequences, dynamic contrast-enhanced MRI shows marked enhancement in the early phase due to the hypervascularity of the lesion. Diffusion WI shows high signal intensity and low ADC values (2-8). The only curative treatment option for mucosal melanoma is wide surgical resection. Chemotherapy is used for systemic treatment or in addition to surgery in metastatic disease, and radiotherapy is used to control the local disease and prevent local recurrence $(9,10)$.

\section{Conclusion}

Primary mucosal malignant melanomas are very rare and have poor prognosis. Knowing typical radiological features in respiratory, gastrointestinal and urogenital tract lesions, and considering it for differential diagnosis in clinical evaluation will increase the chance of early diagnosis.

Informed Consent: Written informed consent was not obtained from the patients due to retrospective design of the study.

Peer-review: Externally peer-reviewed.

Author Contributions: Concept - K.E.Ç.; Design - C..E.; Supervision Y.K., Ö.K.; Resources - K.E.C.; Materials - C.L.; Data Collection and/or Processing - Y.K.; Analysis and/ or Interpretation - C..E.; Literature Search - K.E.C.; Writing Manuscript - K.E.C..; Critical Review - K.E.C.., Y.K., Ç.E., C.L., Ö.K.

Conflict of Interest: No conflict of interest was declared by the authors.

Financial Disclosure: The authors declared that this study received no financial support.

\section{References}

1. Mihajlovic M, Vlajkovic S, Jovanovic P, Stefanovic V. Primary mucosal melanomas: a comprehensive review. Int J Clin Exp Pathol 2012; 5: 739-53.

2. Keraliya AR, Krajewski KM, Braschi-Amirfarzan M, Tirumani SH, Shinagare $A B$, Jagannathan JP, et al. Extracutaneous melanomas: a primer for the radiologist. Insights into imaging 2015; 6: 707-17.

3. Seetharamu N, Ott PA, Pavlick AC. Mucosal melanomas: a case-based review of the literature. Oncologist 2010; 15: 772-81.

4. Baderca F, Cojocaru S, Lazar E, Lazureanu C, Lighezan R, Alexa A, et al. Amelanotic vulvar melanoma: case report and review of the literature. Rom J Morphol Embryol 2008; 49: 219-28.

5. Carvajal RD, Spencer SA, Lydiatt W. Mucosal melanoma: a clinically and biologically unique disease entity. J Natl Compr Canc Netw 2012; 10: 345-56.

6. Baderca F, Vincze D, Balica N, Solovan C. Mucosal melanomas in the elderly: challenging cases and review of the literature. Clin Interv Aging 2014; 9: 92937. 
7. O'Regan K, Breen M, Ramaiya N, Jagannathan J, DiPiro PJ, Hodi FS, et al. Metastatic mucosal melanoma: imaging patterns of metastasis and recurrence. Cancer Imaging 2013; 13: 626-32.

8. Liu QY, Zeng YP, Lin XF, Liu ZF, Wu XF, Li HG. MRI findings in primary vaginal melanoma - a report of four cases. Clin Imaging 2015; 39: 533-7.
9. Gunbey HP, Gunbey E, Sayit AT, Aslan K. Magnetic Resonance Imaging (MRI) appearances of primary amelanotic malign melanoma in the nasal cavity: A rare case. J Clin Diagn Res 2015; 9: 1-3.

10. Bridger AG, Smee D, Baldwin MA, Kwok B, Bridger GP. Experience with mucosal melanoma of the nose and paranasal sinuses. ANZ J Surg 2005; 75: 192-7. 